\section{Sammenhengen mellom personlighet og kreft}

\section{Det er ingen holdepunkter for at personligheten er en direkte årsaks- faktor ved kreft, men effekten kan være indirekte gjennom personlig- hetens sterke innflytelse på livsstil.}

Selv om jakten på en kreftdisponerende personlighet er avblåst, har ulike personlighetstrekk betydning for hvordan individer forholder seg til fasene av sykdomsforløpet ved kreft. En ny artikkel gir for første gang en samlet fremstilling av betydningen av nervøsitet, utadvendthet, optimisme og samvittighetsfullhet for kreftsykdom (1). Selv om konklusjonen fra studier er at personligheten ikke er en risikofaktor for kreft, kan det innvendes at det i studiene er brukt for enkle statistiske modeller. Det betyr at siste ord ikke er sagt i så måte.

Sterk nervøsitet og liten optimisme gir mindre sjanse for at man møter til screening, og økt risiko for sterke psykiske reaksjoner på gentesting. De samme personlighetskonstellasjonene er sterkt assosiert med utmat- telse (fatigue), psykiske plager og dårlig livskvalitet samt høyt nivå av rapporterte bivirkninger etter kreftbehandlingen. Kraftig nervøsitet er assosiert med generell overdødelighet, men ikke med kreftspesifikk overdødelighet.

Om kreftopplevelsen endrer personligheten til pasientene, er mer usikkert, særlig med tanke på såkalt posttraumatisk vekst etter kreft. Betydningen av personligheten for mestring av palliativ fase er lite studert. Personligheten betyr mye for valget av livsstil, som i sin tur har betydning for om kreft oppstår og for mulighetene av residiv.

Å stille noen få spørsmål om nervøsitet kan være klinisk nyttig for å identifisere kreftpasienter med økt risiko for bivirkninger og problemer.

\section{Alv A. Dahl}

alv.a.dahl@oslo-universitetssykehus.no

Oslo universitetssykehus

\section{Litteratur \\ Dahl AA. The link between personality problems and cancer. Future Oncol 2010; 6: 691-707.}

\section{Tannbehandling kan øke risiko for karsykdom}

\author{
Risikoen for hjerneslag og hjerte- \\ infarkt øker forbigående i ukene \\ etter omfattende tannlege- \\ behandling.
}

Akutt og kronisk inflammasjon ser ut til å ha betydning for forekomsten av hjerteog karsykdom. I en amerikansk studie ble 650 pasienter som var blitt utskrevet fra sykehus etter sitt første hjerneslag og 525 utskrevet etter sitt første hjerteinfarkt i perioden 2002-06, inkludert i en selvkontrollerende kasusstudie (1). Alle hadde gjennomgått invasiv tannlegebehandling minst 24 uker tidligere.

Forekomsten av hjerneslag og/eller hjerteinfarkt var høyere de første fire ukene etter tannlegebehandling enn i noen annen tidsperiode (insidensratio 1,50; 95 \% KI 1,09-2,06) og avtok så til utgangspunktet innen seks måneder. Assosiasjonen var uendret etter eksklusjon av personer med diabetes, hypertensjon og koronar hjertesykdom og personer behandlet med antikoagulantia.

- Denne studien tyder på at invasive dentale prosedyrer kan være assosiert med en forbigående økt risiko for hjerneslag og hjerteinfarkt, sier professor Ingar Olsen ved Det odontologiske fakultet, Universitetet i Oslo. Dette kan ha sammenheng med en forbigående akutt inflammasjon og endotelial dysfunksjon som følge av slike inngrep.

Studien forsterker hypotesen om at akutt inflammasjon har betydning for hjerte- og karsykdommer. I Oslo har vi nylig funnet at tannekstraksjon pga. infeksjon hos eldre menn kan være assosiert med hjerteinfarkt. Den absolutte sykdomsrisikoen er likevel liten. Sannsynligvis er kronisk utsiving av bakterier og bakterieprodukter og proinflammatoriske mediatorer fra kroniske orale infeksjoner av større betydning enn invasiv tannbehandling, sier Olsen.

\section{Arne Johan Norheim
arne.johan.norheim@hlink.no}

Nasjonalt forskningssenter innen komplementær og alternativ medisin (NAFKAM)

Universitetet i Troms $\emptyset$ og

Rødbergveien legesenter 9497 Harstad un et fåtall har fått tilbud om behand Begrensede helseressurser og manglende kunnskap har ført til fattigdom og invaliditet for svært mange unge mennesker.

Ponsetis prinsipper er foretrukket behandling ved alle landets sykehus fordi det er en relativt lite invasiv behandlingsmetode (2). Manipulasjon, skinner og gipsbehandling kan langt på vei være et alter-
Litteratur
1. Pirani S, Naddumba E, Mathias R et al. Towards effective Ponseti clubfoot care: the Uganda Sustainable Clubfoot Care Project. Clin Orthop Relat Res 2009; 467: 1154-63.
2. Dobbs MB, Gurnett CA. Update on clubfoot: etiology and treatment. Clin Orthop Relat Res 2009; 467: 1146-53.

\section{Petter Gjersvik \\ petjense@online.no \\ Tidsskriftet}

\section{Litteratur}

1. Minassian C, D'Aiuto F, Hingorani AD et al. Invasive dental treatment and risk for vascular events. A self-controlled case series. Ann Intern Med 2010; 153: 499-506. 